\title{
The life and death of Helicobacter pylori
}

\author{
D Scott, D Weeks, K Melchers, G Sachs
}

\begin{abstract}
Summary
The ability of Helicobacter pylori to survive in the varying acidity of the stomach is considered to be linked to its ability to maintain a tolerable $\mathrm{pH}$ in its periplasmic space by acid dependent activation of internal urease activity. Whereas survival of $H$ pylori can occur between a periplasmic $\mathrm{pH}$ of 4.0 to 8.0 , growth can only occur between a periplasmic $\mathrm{pH}$ of 6.0 to 8.0. When urease activity is only able to elevate periplasmic $\mathrm{pH}$ to between 4.0 and 6.0 , the organisms will survive but not divide. In the absence of division, antibiotics such as clarithromycin and amoxycillin are ineffective. Proton pump inhibitors, by elevating gastric $\mathrm{pH}$, would increase the population of dividing organisms and hence synergise with these antibiotics.
\end{abstract}

\section{Introduction}

Colonisation of the normal stomach has been achieved only by Helicobacter spp., such as $H$ pylori, $H$ felis or $H$ mustelae. These are Gram negative, motile, aerobic, spiral shaped organisms that dwell on the gastric surface and within the gastric mucus. They are found more frequently in the antrum than in the fundus and often within antral glands. They grow in vitro between $\mathrm{pH} 6.0$ and 8.5 and survive between $\mathrm{pH} 4.0$ and 8.5 in the absence of urea. ${ }^{1}$

\section{The gastric environment}

The $\mathrm{pH}$ of the gastric lumen in humans is quite variable. The median $\mathrm{pH}$ is 1.4 , but this is severely skewed by a low volume, highly acidic secretion at night where there is no buffering by food. The $\mathrm{pH}$ can fall to below 1.0 with acid secretion in the absence of buffering by food. Even with proton pump inhibition there are rapid excursions of high acidity. ${ }^{2}$ The $\mathrm{pH}$ at the gastric surface is thought to be significantly higher than in the lumen. $\mathrm{pH}$ microelectrode experiments indicate that the surface $\mathrm{pH}$ may be close to neutral when luminal $\mathrm{pH}$ is as low as 2.0 but this gradient is not maintained when the $\mathrm{pH}$ falls below 2.0. ${ }^{3}$ Two concepts have been put forward to explain the higher $\mathrm{pH}$ at the gastric surface-namely the presence of a mucus barrier and $\mathrm{HCO}_{3}$ secretion. $\mathrm{HCO}_{3}$ secretion is able to neutralise $10 \%$ of maximal acid secretion. Thus the increase in $\mathrm{pH}$ to 6.0 from a medium $\mathrm{pH}$ of 2.0 would be feasiblethat is, the secretion of 10 to $20 \mathrm{mM} \mathrm{HCO}_{3}$ would be able to neutralise 10 to $20 \mathrm{mM} \mathrm{HCl}$ but not $100 \mathrm{mM}$. The $\mathrm{pH}$ of the lumen of the fundic glands, the source of $\mathrm{HCl}$, is much lower, as can be estimated from the uptake of the weak base ${ }^{14} \mathrm{C}$ aminopyrine by rabbit gastric glands in vitro. The $\mathrm{pH}$ on the antral surface where there is no acid secretion is likely to be higher than on the gastric fundic surface but relative measurements of these two regions have not been published. Helicobacteria therefore are exposed to two types of acidic stress: chronic and acute. The magnitude of this acid stress on the surface of the human stomach is not known.

\section{Microbial acid adaptation}

Bacteria have adapted remarkably to variations in the acidity of their environment. For Gram negative organisms, which possess two membranes enclosing a periplasmic space, it is the $\mathrm{pH}$ of this space that is important for their survival or growth. Those which are capable of tolerating only a $\mathrm{pH}$ range of 4.0 to 8.0 in the periplasmic space may be classified as neutralophiles, those which have adapted to a $\mathrm{pH}$ as low as 2.0 may be facultative or obligate acidophils, whereas those that tolerate $\mathrm{pH}$ as high as 10 can be thought of as alkalophils. Those that can only survive but not grow in acid are acid resistant neutralophiles and finally, and particularly relevant to Helicobacteria, those that grow best at neutral $\mathrm{pH}$ but are able to survive and grow in acidity and to increase their periplasmic $\mathrm{pH}$ in the presence of acid by specialised mechanisms can be regarded as acid tolerant neutralophiles.

Different mechanisms have evolved but all are designed to maintain a tolerable electrochemical gradient of $\mathrm{H}^{+}$across the inner membrane of these bacteria. This can be achieved by alterations in transmembrane potential so that true acidophils respond to acidity by the generation of an inward positive potential, thus reducing the effective gradient. True alkalophils increase their inner membrane potential in order to increase the effective electrochemical gradient of hydrogen ions. Acid tolerance can be achieved by the generation of neutralising buffers either inside the cell or in the periplasmic space. Many bacteria respond to acidity by changes in gene expression of specialised proteins. At this time there are few gene sequences known for true acidophils so it is difficult to compare these sequences with similar sequences available from the $H$ pylori genome.

Infection and colonisation of the human stomach requires more than one mechanism of acid adaptation. The frequently highly acidic $\mathrm{pH}$ of gastric contents requires high acid resistance in transit to the site of colonisation on the gastric surface. Growth on the surface requires acid tolerance as the $\mathrm{pH}$ here may be higher than in the gastric lumen but is still acidic in nature. Finally, different mechanisms may have evolved in terms of a response to acute as compared with chronic acidification of the bacterial environment. An understanding 
of these mechanisms of acid tolerance may lead directly to a Helicobacteria specific means of eradication of the organism.

\section{Molecular mechanisms of acid adaptation of Helicobacteria}

STRUCTURAL ASPECTS OF MEMBRANE PROTEINS The outer membrane of Gram negative organisms is a phospholipid bilayer containing a variety of proteins, some membrane spanning, some associated with only one face of the bilayer as well as lipopolysaccharides. The outer membrane spanning proteins such as porins are able to mediate the flux of various small molecules across the outer membrane. There are several porins in Helicobacteria as defined by cloning ${ }^{4}$ and genomic analysis. ${ }^{5} \mathrm{~A}$ means of acid protection would be to alter the isoelectric point of these proteins as a means of reducing the transport of protons across the bilayer. As a group, these Helicobacteria porins and some inner membrane proteins have an isoelectric point significantly more alkaline than that of bacteria rarely exposed to acid. Thus these proteins are more positively charged in acid than those of neutralophiles such as Escherichia coli, thereby retarding flux of protons into the periplasmic space. An example of this is the $c$ subunit of the $F_{1} F_{0}$ ATP synthase. This inner membrane proteolipid is responsible for the proton flow across the membrane enabling ATP synthesis. There is a loss of four carboxylic amino acids in the sequence of the $H$ pylori proteolipid compared with that of $E$ coli or $B$ subtilis.

This increase in isoelectric point suggests that both the outer and inner membrane of the organism can be exposed to high acidity, and that the relative increase in numbers of positively charged amino acids or decrease in the number of carboxylic acids in the membrane proteins provides a degree of resistance to acid present on the outer surface and perhaps occasionally on the outer face of the inner membrane of $H$ pylori. The most likely use of this adaptive mechanism is acid resistance when the organism is exposed directly to luminal acidity.

Kinetic retardation of proton flux can only provide transient protection and other mechanisms must be present to allow both long term survival and growth in the gastric environment. Thus, the finding that $H$ pylori is killed within a few minutes by $\mathrm{pH}<4.0$ in vitro in the absence of urea provides evidence for the presence of other mechanisms enabling acid tolerance. ${ }^{16}$

ATP SYNTHESIS AND MEDIUM $\mathrm{pH}$

The survival of aerobic bacteria depends largely on their ability to synthesise ATP, probably by hydronium flux inward across the $\mathrm{F}_{1} \mathrm{~F}_{0}$ ATPase driven by an inwardly oriented electrochemical gradient of $\mathrm{H}_{3} \mathrm{O}^{+} .{ }^{7}$ The gradient is the sum of the $\mathrm{pH}$ gradient and the potential difference, the proton motive force (PMF):

$\mathrm{PMF}($ in $\mathrm{mV})=\Delta \overline{\mathrm{u}}_{\mathrm{H}^{+}}=-\mathrm{RT} / \mathrm{nF} \ln \left[\mathrm{H}^{+}{ }_{\text {out }}\right] /$

$\left[\mathrm{H}^{+}{ }_{\text {in }}\right]+\Delta \psi=-61 \Delta \mathrm{pH}+\mathrm{PD}$

In a neutralophile such as $E$ coli, in a medium of $\mathrm{pH} 7.0$, the cytoplasmic $\mathrm{pH}$ is about 7.5 to 7.8 and the transmembrane potential is about
$-160 \mathrm{mV}$, to give an electrochemical gradient of about $-200 \mathrm{mV}$. Measurement of the membrane potential of $H$ pylori in the absence of urea at $\mathrm{pH} 7.0$ gave a value of $-131 \mathrm{mV}$ and an internal $\mathrm{pH}$ of 8.4. This higher internal $\mathrm{pH}$ is consistent with the lower proton permeability of the membranes of this organism. The proton motive force measured for $\mathrm{H}$ pylori is therefore about $-220 \mathrm{mV}{ }^{6}$

This bacterium is able to maintain a membrane potential between $\mathrm{pH} 4.0$ and 8.5. If the $\mathrm{pH}$ was outside these limits there was a relatively rapid and irreversible loss of the membrane potential, which correlated well with the measured survival of the organism at different $\mathrm{pH}$ values in the absence of urea. The addition of urea restored the membrane potential within about one minute at $\mathrm{pH} 3.5$, prior to measured medium alkalinisation. Addition of urea at neutral $\mathrm{pH}$ in the absence of buffer resulted in medium alkalinisation to a $\mathrm{pH}>8.5$ and loss of membrane potential. Hence urease activity is a two edged sword for $\mathrm{H}$ pylori, enabling survival in acid, preventing survival in the absence of acid. ${ }^{17}$

REGULATION OF PERIPLASMIC pH IN ACID As pointed out above, simply retarding $\mathrm{H}^{+}$ penetration into the periplasmic space or cytoplasm of $H$ pylori would not ensure its survival in the stomach, let alone growth. A remarkable feature of this organism is its synthesis of a neutral $\mathrm{pH}$ optimum urease at high concentrations. Indeed $15 \%$ of the protein synthesis is devoted to the production of ure $\mathrm{A}$ or ure $\mathrm{B}$, the peptides that constitute, along with $\mathrm{Ni}^{2-}$, the active urease enzyme.

The reaction catalysed by urease is: $\mathrm{CO}\left(\mathrm{NH}_{2}\right)_{2}+\mathrm{H}_{2} \mathrm{O} \rightarrow \mathrm{NH}_{3}+\mathrm{HCOONH}_{2} \rightarrow$ $\mathrm{NH}_{3}+\mathrm{CO}_{2}$

$H$ pylori has a prokaryotic carbonic anhydrase in its genomic sequence, ${ }^{5}$ hence the eventual effect of urease activity; at a $\mathrm{pH}$ less than the $\mathrm{pK}_{\mathrm{a}}$ of $\mathrm{NH}_{3}$ (9.5) and greater than 4.8 (the effective $\mathrm{pK}_{\mathrm{a}}$ of bicarbonate due to the volatility of $\mathrm{CO}_{2}$ ), is:

$\mathrm{CO}\left(\mathrm{NH}_{2}\right)_{2}+2 \mathrm{H}_{2} \mathrm{O}+\mathrm{H}^{+} \rightarrow 2 \mathrm{NH}_{4}^{+}+\mathrm{HCO}_{3}^{-}$ which therefore is able to alkalinise the environment of the urease.

Investigation into the localisation of the urease of the organism rapidly showed that significant urease activity was found outside the organism either in solution or bound to the cell surface. ${ }^{8910} \mathrm{~A}$ prevailing hypothesis suggests that surface urease activity reduces the acidity of the microenvironment of the organism below the mucus layer of the gastric mucosa. This microenvironment could in principle be located external to the organism or in the periplasmic space but as surface urease was designated as the responsible urease compartment, it was neutralisation of the external microenvironment that was given most attention.

Figure 1 shows the measurement of the $\mathrm{pH}$ optimum of urease of $H$ pylori after 24 hour culture. Free urease or urease bound to the surface shows a $\mathrm{pH}$ optimum between 7.5 and 8.0 as has been described previously. ${ }^{11}{ }^{12} \mathrm{How}-$ ever, at a $\mathrm{pH}$ of 4.5 or below there is little if any demonstrable urease activity. Hence, either the 


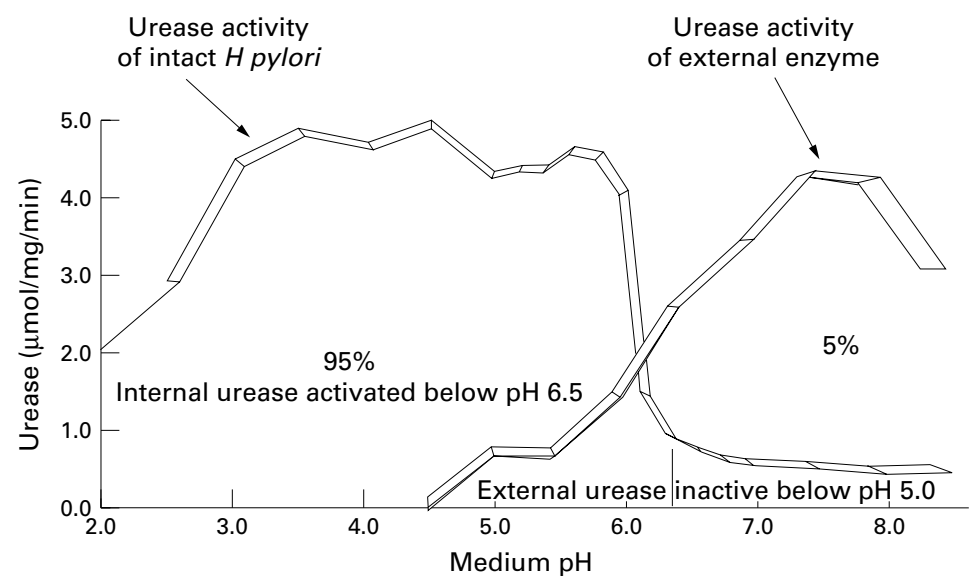

Figure 1 Comparison of the $p H$ optimum of urease external to $H$ pylori and urease in intact organisms illustrating the 10-fold activation in intact organisms seen between $p H 6.5$ and 5.5.
RESPONSE TO ELEVATED $\mathrm{pH}$

$H$ pylori survive between $\mathrm{pH} 4.0$ and 8.2. ${ }^{16}$ The addition of urea enables survival at $\mathrm{pH}$ levels down to 2.0. However at neutral $\mathrm{pH}$ with little buffering, the addition of urea elevates medium $\mathrm{pH}$ to 8.5 or greater, with a resultant irreversible loss of membrane potential and death. ${ }^{6}$ Hence external urease is toxic at neutral $\mathrm{pH}$. This latter effect may explain the absence of $H$ pylori infection in pernicious anaemia. ${ }^{14}$

If external urease were essential for the organism's viability in the stomach, survival would presumably depend on secretion of the enzyme. If bacteria are grown in labelled methionine for four to 24 hours, a large variety of proteins are labelled. In the medium, there is little labelled protein seen until 16 hours and then the labelling pattern of the protein in the medium is largely identical to that found in the bacteria. From this, it can be concluded that the major means of externalisation of the urease is by bacterial lysis (fig 2). ${ }^{13} 15$ This has been called altruistic cell death, implying that external urease serves a purpose for survival of the bacteria. ${ }^{15}$ But as this urease is inactive at $\mathrm{pH} 4.5$ and the bacteria can survive this acidity quite readily without urea being present in the medium, altruism seems an inappropriate description.

In summary, internal urease is active at a gastric $\mathrm{pH}$ of $<6.5$ and enables survival and growth at $\mathrm{pH}$ between perhaps 2.0 and 6.0 depending on the gastric urea concentration in the environment of the organism. Since the $\mathrm{K}_{\mathrm{m}}$ of urease is about $1 \mathrm{mM}$, urea concentrations for effective internal enzyme activity in the absence of concentrative mechanisms would

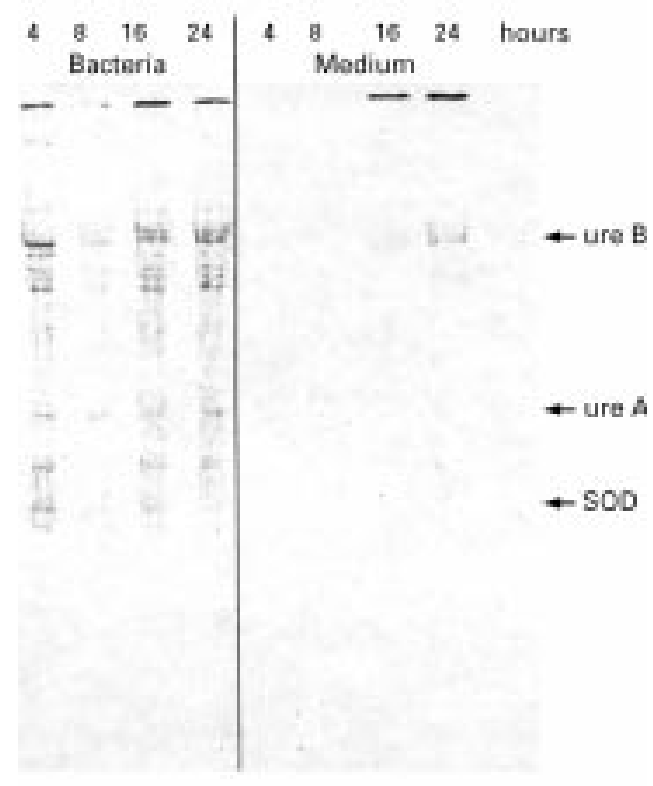

Figure 2 Comparison of protein labelling as a function of time using ${ }^{35} S$-methionine to label the protein. The four lanes on the right represent proteins synthesised in intact $H$ pylori and the four lanes on the left the medium in which these were suspended. Significant quantities of labelled protein only appear in the medium after about 16 hours of incubation. The protein in the medium shows the same relative labelling pattern as in the whole bacteria. This image is typical of at least three experiments. SOD, superoxide dismutase. 


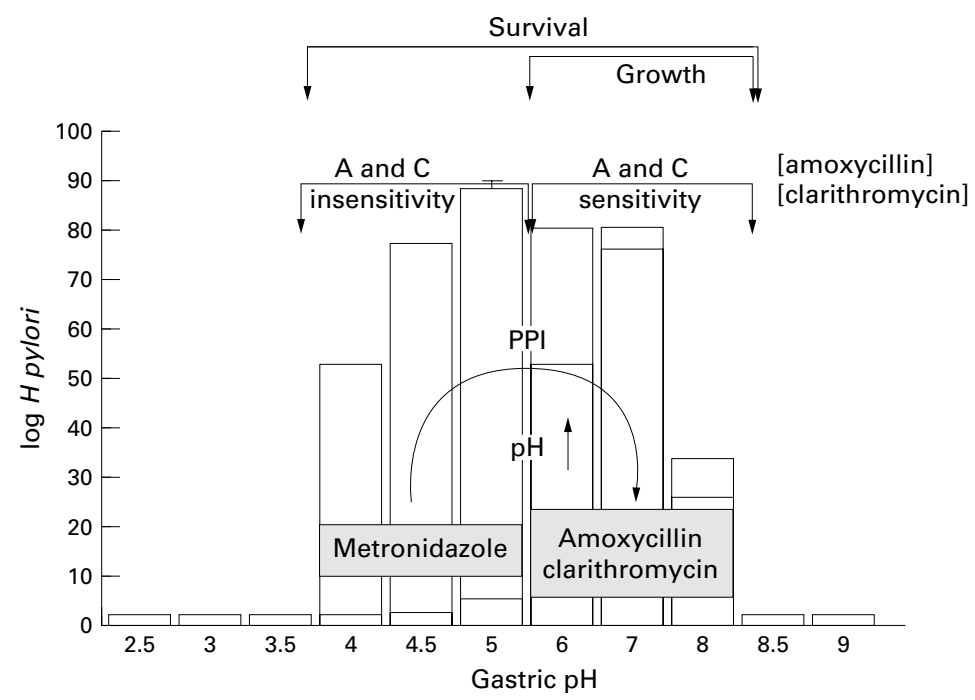

Figure 3 Comparison of the $p H$ range over which $H$ pylori survives to the $p H$ range at which it grows or synthesises protein in the absence of urea. On the figure we indicate the range for which antibiotic sensitivity is expected and illustrate the theoretical effect of proton pump inhibition (PPI) on the population distribution of $H$ pylori between dividing and non-dividing organisms. $A$, amoxycillin; $C$, clarithromycin.

have to be at least $0.1 \mathrm{mM}$ and probably closer to the $\mathrm{K}_{\mathrm{m}}$. External urease does not function as a gastroprotective mechanism but impedes survival elsewhere in the gut, perhaps reducing the immune response that would occur if intact antigens were presented in large quantities to the Peyer's patches of the intestine.

\section{The ecological niche of $H$ pylori}

From the above, survival of $H$ pylori in the presence of urea under the low buffering conditions of the gastric mucosa is confined to a $\mathrm{pH}$ between about 2.0 and 6.5. The exact $\mathrm{pH}$ limits are defined by the prevailing urea concentration and urease activity: growth or protein synthesis is over a narrower range of $\mathrm{pH}$-namely between $\mathrm{pH} 6.0$ and 8.0. Hence for effective colonisation, the periplasmic $\mathrm{pH}$ must be kept within those boundaries. It has been shown that $5 \mathrm{mM}$ urea is able to elevate periplasmic $\mathrm{pH}$ to close to 6.2 over a $\mathrm{pH}$ range of 3.0 to 6.0 . At $1 \mathrm{mM}$ urea, which is a reasonable concentration for gastric juice, the internal urease activity should be able to elevate periplasmic $\mathrm{pH}$ also within this range of gastric $\mathrm{pH}$. Hence $H$ pylori would inhabit only those regions of the gastric mucosal surface that remain largely within this $\mathrm{pH}$ range. In general, fundic $\mathrm{pH}$ in the region of acid secretion would often exceed these limitations and population of this region would be sparse. Antral pH may well be within this range, given the absence of acid secretion and the presence of $\mathrm{HCO}_{3}$ secretion in this area. Therefore a larger number of organisms are expected in this region of the stomach, as has generally been found.

The organism is motile and therefore has a random ability to move between different regions of the stomach. There is no published evidence that there is either positive or negative $\mathrm{pH}$ driven chemotaxis of Helicobacteria. If the gastric $\mathrm{pH}$ is changed, as would happen with treatment with proton pump inhibitors, it would be expected that the intragastric population would tend to redistribute on the gastric surface driven by the ability of the bacteria to colonise the gastric surface where the $\mathrm{pH}$ is between 3.0 and 6.0. Treatment with such drugs on once a day therapy elevates intraluminal $\mathrm{pH}$ from an average of 1.4 to an average of about 3.5 . However, only $70 \%$ of acid secretory capacity is lost at steady state inhibition. ${ }^{16}$ The fundic surface would therefore remain acidic, although less so, and the antral surface may reach close to neutrality under these conditions.

Hence with proton pump inhibition, the antrum would tend to lose organisms as the immediate $\mathrm{pH}$ at least in some regions would reach a $\mathrm{pH}$ of 6.5 or greater, and the fundus would tend to acquire organisms where the surface $\mathrm{pH}$ would exceed 3.0. This redistribution of $H$ pylori has indeed been found in individuals treated with proton pump inhibitors. ${ }^{17}$ This analysis also permits the conclusion that in humans, fundic surface $\mathrm{pH}$ is usually below 3.0 and antral surface $\mathrm{pH}$ generally above 3.0.

\section{Strategies for eradication}

Currently there are two types of treatment recommended for eradication. One uses a combination of antisecretory therapy in the form of ranitidine in combination with bismuth subcitrate (RBC), a formulation claimed to generate a more soluble form of bismuth as well as two antibiotics and may be regarded as quadruple therapy. The mechanism of action of bismuth is not known. As a divalent cation it may act as a surrogate for other divalent cations interfering with transition metal import or export via the three known P type ATPases or substitute for a divalent cation in an essential enzyme.

The other type of therapy recommends a proton pump inhibitor, to be used once or twice a day in combination with two antibiotics, selected from amoxycillin, clarithromycin or metronidazole. The reason for the synergism between proton pump inhibitors and either amoxycillin or clarithromycin is not experimentally established, but a rationale can be proposed based on the acid dependent biology of the organism discussed earlier. Both the above therapies are effective after seven days of dosing. Controlled clinical trials give eradication rates of between 80 and $90 \% .^{18}$

The survival of $H$ pylori occurs between $\mathrm{pH}$ 4.0 and 8.0, whereas protein synthesis occurs between $\mathrm{pH} 6.0$ and 8.0. Hence between $\mathrm{pH}$ 4.0 and 6.0, $H$ pylori does not divide. As both clarithromycin and amoxycillin require growth, those bacteria present in the non-dividing state will be resistant to these antibiotics. If nondividing $H$ pylori is present on the gastric surface during the time of exposure to either clarithromycin or amoxycillin, either topically or systemically, these organisms will not be eradicated. Elevation of surface $\mathrm{pH}$ by the administration of a proton pump inhibitor will move at least some of these organisms from a non-dividing into a growth or dividing state, allowing bactericidal or bacteriostatic effects of these antibiotics. If the $\mathrm{pH}$ in antral regions increases to close to neutrality, these organisms 
will be killed by the proton pump inhibitor alone. Hence the synergism observed is likely to be due to a $\mathrm{pH}$ elevation dependent increase in the antibiotic sensitive population. Metronidazole, a DNA targeted antibiotic, does not depend on cell division for its activity, therefore synergism between proton pump inhibitors and metronidazole is not observed. Figure 3 illustrates these principles.

The use of these antibiotics is likely to become more limited as resistance develops. Furthermore, if eradication is to be extended to the infected population at large there is a risk of generating resistance in other pathogens. Hence monotherapy is desirable with a compound that is specific for $H$ pylori. The logical approach is to evaluate the acid resistance mechanisms and target any one of the systems that are essential for life in an acidic environment.

Supported by US VA SMI funds and NIH grant nos DK40615, 41301 and 17294

1 Clyne M, Labigne A, Drumm B. Helicobacter pylori requires an acidic environment to survive in the presence of urea. Infect Immun 1995;63:1669-73.

2 Katzka DA, Paoletti V, Leite L, et al. Prolonged ambulatory $\mathrm{pH}$ monitoring in patients with persistent gastroesophageal reflux disease symptoms: testing while on therapy identifies the need for more aggressive anti-reflux therapy. Am $f$ Gastroenterol 1996;91:2110-13.

3 Schade C, Flemstrom G, Holm L. Hydrogen ion concentration in the mucus layer on top of acid-stimulated and -inhibited rat gastric mucosa Gastroenterology 1994;107: $180-8$.
4 Doig P, Trust TJ. Identification of surface-exposed outer membrane antigens of Helicobacter pylori. Infect Immun 1994;62:1526-33.

5 Tomb JF, White O, Kerlavage AR, et al. The complete genome sequence of the gastric pathogen Helicobacter pylori. Nature 1997;388:539-47.

6 Meyer-Rosberg K, Scott DR, Rex D, et al. The effect of environmental $\mathrm{pH}$ on the proton motive force of Helicobacter pylori. Gastroenterology 1996;111:886-900.

7 Mitchell P. Chemosmotic coupling in oxidative and photosynthetic phosphorylation. Biol Rev 1966;41:145502.

8 Hawtin PR, Stacey AR, Newell DG. Investigation of the structure and localization of the urease of Helicobacter pylori using monoclonal antibodies. F Gen Microbiol 1990; 136:1995-2000.

9 Bode G, Malfertheimer P, Lenhardt, G, et al. Ultrastructural localization of urease of Helicobacter pylori. Med Microbiol Immun 1993;182:223-42.

10 Dunn BE, Vakil NB, Schneider BG, et al. Localization of Helicobacter pylori urease and heat shock protein in human gastric biopsies. Infect Immun 1997;65:1181-8.

11 Taylor MB, Goodwin CS, Karim QN. Two urease activities with different $\mathrm{pH}$ optima in Campylobacter pylori and similar organisms. FEMS Microbiol Lett 1988;55:259-62.

12 Mobley H LT, Island MD, Hausinger RP. Molecular biology of microbial ureases. Microbiol Rev 1995;59:451-80.

13 Scott DR, Weeks D, Hong C, et al. The role of internal urease in acid resistance of Helicobacter pylori. Gastroenterology 1998;114:58-78.

14 Feljou JF, Bahame P, Smith AC, et al. Pernicious anaemia and Campylobacter like organisms; is the antrum resistant to colonisation? Gut 1989;30:60-4.

15 Phadnis SH, Parlow MH, Levy M, et al. Surface localization of Helicobacter pylori urease and a heat shock protein homolog requires bacterial autolysis. Infect Immun 1995;64: 905-12.

16 Lind T, Cederberg C, Ekenved G, et al. Effect of omeprazole - a gastric acid pump inhibitor - on pentagastrin stimulated acid secretion in man. Gut 1983;24:270-7.

17 Logan RPH, Walker MM, Misiewicz JJ, et al. Changes in the intragastric distribution of Helicobacter pylori during treatment with omeprazole. Gut 1995;36:12-16.

18 Axon ATR. Eradication of Helicobacter pylori. Scand 7 Gastroenterol 1996;31:47-53. 